\title{
Signs, meanings and practices of people living with human t-cell lymphotropic virus type 1 or tropical spastic myelopathy
}

\author{
Genildes Oliveira Santana ${ }^{1 *}$, Ana Mary Libório ${ }^{1}$, Ana Verena Galvão², Milena Pereira Pondé1 and Katia Nunes Sá ${ }^{1}$
}

\begin{abstract}
Background: Human T-cell lymphotropic virus type 1 (HTLV-1) spreads silently in the world's population and causes several syndromes. Among these, HTLV-1 associated myelopathy, also called tropical spastic paraparesis (HAM/TSP), affects the nervous system. It causes sensorimotor losses, spasticity, muscle weakness, voiding and sexual dysfunction, pain, and balance disorders. There is limited knowledge of the feelings, experiences, and coping mechanisms associated with this neglected disease. The objective of the present qualitative study was to investigate the signs, meanings, and practices of people with HAM/TSP, through narratives obtained from focus groups and individual semi-structured face-to-face interviews.

Results: Thirty-eight individuals diagnosed with HAM/TSP participated in the study. The following categories and subcategories emerged from the participants: Signs - physical signs, symptoms, and discovery of the disease;

Meanings — reaction to diagnosis and knowledge of disease, fears, and expectations; Practices—daily life, leisure, religious, and treatment activities.

Conclusions: People with HAM/TSP suffer from symptoms that limit their social participation, and they are affected by complex and multidimensional feelings. This awareness can contribute to the implementation of public policiesfocused on the real perspective of these patients - that provide more directed, empathic, and harmonious care for these individuals.
\end{abstract}

Keywords: Tropical spastic paraparesis, Human T-lymphotropic virus 1, Qualitative research, Psychosocial approach

\section{Introduction}

Human T-cell lymphotropic virus type 1 (HTLV-1) was the first retrovirus identified in humans [1]. Its infection occurs either vertically (breastfeeding) or horizontally (through sexual intercourse, blood transfusion, or contamination with piercing objects) [2]. It is estimated that there are 5 to 10 million infected people worldwide [3], of whom more than 2 million are in Brazil [4]. Salvador is the city with the highest seroprevalence in the country, with $1.76 \%$ of the population affected. The majority of infected people are female with black skin color and low socioeconomic status [5].

\footnotetext{
*Correspondence: genildessantana009@gmail.com

'Department of Post Graduate, Bahiana School of Medicine and Public Health, Salvador, Bahia, Brazil

Full list of author information is available at the end of the article
}

Approximately $3-5 \%$ of HTLV-1-infected people develop HTLV-1 associated myelopathy or tropical spastic paraparesis (HAM/TSP). It is a progressive neurodegenerative condition that predominantly affects the spinal cord and causes chronic pain, postural imbalance, sphincter and sexual disorders, and gait and balance alterations, all of which negatively impact quality of life [6, 7]. Five to ten years after HAM/TSP diagnosis, people need some walking aid [6].

The approach to this health condition has been elaborated based on anatomopathological, clinical, and functional quantitative markers [8]. Similarly, the efficacy of pharmacological and physiotherapeutic interventions is tested by evaluating quantifiable outcomes [9-12]. Listening to the "voices" of people who live with HAM/ TSP, with regards to the symptoms, perceptions,

\section{Springer Open}

() The Author(s). 2020 Open Access This article is licensed under a Creative Commons Attribution 4.0 International License, which permits use, sharing, adaptation, distribution and reproduction in any medium or format, as long as you give appropriate credit to the original author(s) and the source, provide a link to the Creative Commons licence, and indicate if changes were made. The images or other third party material in this article are included in the article's Creative Commons licence, unless indicated otherwise in a credit line to the material. If material is not included in the article's Creative Commons licence and your intended use is not permitted by statutory regulation or exceeds the permitted use, you will need to obtain permission directly from the copyright holder. To view a copy of this licence, visit http://creativecommons.org/licenses/by/4.0/. 
feelings, perspectives, and ways of coping, can help to uncover questions that quantitative research does not achieve. Indeed, although much is known about the biomedical aspects of HAM/TSP, little is known about the effect of the disease and therapeutic protocols on psychosocial parameters [13]. Assessing the perception of affected people can reveal subjective aspects that affect the results of therapeutic interventions and clinical evolution. It can also help establish grounds for health actions recommended by the World Health Organization (WHO) for neglected diseases [14].

Qualitative research aims to gather systematic knowledge on the ways of thinking and acting for specific populations. The analysis of signal systems, meanings and practices is grounded in the study of patients' narratives about their experience with a disease. Based on interpretative anthropology, this analytical model investigates the subjective experience of illness and treatment in different sociocultural contexts [15]. Thus, the main objective of the present study was to investigate the signs of the disease process, meanings attributed to the experience and treatments of the disease, and reactive and self-care practices, expressed in the cultural networks of people living with HAM/TSP.

\section{Methods}

\section{Study design and participants}

This study was a descriptive and exploratory examination with a qualitative approach. The study sought to systematize narratives from participants via focus groups (FGs) and face-to-face semi-structured interviews. Information analysis was based on the system of culturally constructed signs, meanings, and practices. It was conducted at the Advanced Physiotherapy Clinics (CAFIS) of the Teaching Assistance Ambulatory, Bahiana School of Medicine and Public Health, located in Salvador, Bahia, Brazil. The population was comprised of patients diagnosed with HAM/TSP who were enrolled in the Integrative and Multidisciplinary Centre for Assistance and Research to Family and HTLV Carriers (CHTLV) of the Bahiana School of Medicine and Public Health in 2014.

\section{Recruitment and sampling}

Enrollment in the study was intentional and voluntary; it occurred via an invitation that was presented to CHTLV participants who were participating in another research project [16]. Fifty-six people who were part of the clinical trial were invited to participate in the present study. Thus, 38 individuals were included in the final sample. They were distributed in the FGs, represented by the code $\mathrm{G}$, or the interviews, represented by the code $\mathrm{E}$. The groups were still coded by the participants with the letter $\mathrm{P}$ and numbered from 1 to 38 (which represented each participant).
Participants were included if they had a confirmed diagnosis of HTLV-1 infection by enzyme-linked immunosorbent assay (ELISA) and western blot exam, clinical diagnosis for HAM/TSP according to Castro-Costa et al. criteria [17], were enrolled in CHTLV, and were above 18 years of age. Patients were excluded if they had difficulties understanding questions or communicating.

\section{Procedures}

Data collection was performed by a researcher with experience in the FG and semi-structured interview techniques. The main researcher (the facilitator) is a physiotherapist, a master in Human Development and Social Responsibility for 25 years with 32 years of clinical practice. The facilitator was accompanied by two undergraduate students from the Physical Therapy course at the Bahiana School of Medicine and Public Health. The students were trained by the researcher. One served as an observer, responsible for making notes of aspects observed in the dynamics of the FG, and the other undergraduate student was responsible for audio recordings. The researcher spoke in person to the participants to invite them to a FG. On the eve of each FG, the researcher confirmed the time and place of the meeting via telephone.

A total of 11 FGs were created, out of which 6 were categorized as pre-training, meaning they took place after the first evaluation for the RTC. These 6 FGs were constituted as follows: FG1 (1 man and 4 women); FG2 ( 2 men and 3 woman); FG3 (2 men and 1 woman); FG4 ( 4 men and 4 women); FG5 ( 2 men and 4 women); FG6 ( 2 men and 3 women). Some participants reports that they had no time, transportation, company, or financial availability or they had other commitments to medical consultations and/or treatments at the same time as the survey. After training and the last evaluation at the ECR, 13 participants of the pre-training group attended the 5 post-training FG in addition to 3 new participants. These groups were formed as follows: FG7 (1 man and 3 women); FG8 (3 women); FG9 (2 men and 1 woman); FG10 ( 2 men and 1 woman) and FG 11 (3 women). FGs were performed for approximately $1.5 \mathrm{~h}$.

FGs are group discussions, organized to explore a specific set of issues, where participants can interact, explore each other's arguments, and express topics they consider important [18].. It also provides the interpretation of beliefs, values, concepts, conflicts, confrontations, and points of view [19]. These features are why it was one of the techniques selected for this research.

The FG environment should be pleasant, comfortable, and warm. Thus, we opted for the use of incense, which lightly perfumed the room, relaxing music with sounds of water and nature, and snacks throughout the meeting [20]. Each FG was conducted in a private setting in the 
physiotherapy clinic (CAFIS). The location of the room allowed the meetings to proceed without external interference. This design facilitated the debate and ensured privacy, comfort, easy access, and a neutral environment [21]. The availability of the chairs in a circle allowed face-to-face interaction, good eye contact, and the same field of view for everyone [21]. After clarifying the objectives of the study and providing written informed consent, the participants were invited to relax and the procedures recommended by Iervolino and Pelicione [22] were adopted. Relaxation and integration techniques were used prior to the application of the method. Semistructured interviews were conducted in a private, airconditioned room at the CAFIS. The guide for the questions used in the FG and interviews are described below.

\section{Guiding questions of the pre-treatment FG}

How did you discover the disease?

How did you get the diagnosis?

What were the symptoms?

What is the relationship of exercises to your health problem?

What do you expect from participation in this project?

What reasons could prevent your participation in this project?

\section{Guiding questions for post-treatment FG}

Were your expectations reached?

How was your participation?

Did you comply with the protocol?

Did you notice changes in your condition?

Semi-structured interviews were also performed with 12 participants, out of which 8 were FG participants and 4 new members that participated in the RCT control group. 7 men and 5 women were interviewed. Twelve interviews were sufficient to reach data saturation because the information generated in the last interviews was repeated and no new code emerged. The average duration of the interviews was approximately $1 \mathrm{~h}$. Semistructured interviews were conducted in a private, airconditioned room at the CAFIS. Semi-structured interview questions: How is your day-to-day activity? How do you do your exercise as part of your day-to-day routine?

\section{Analytical approach}

The analysis of the systems of signs, meanings and practices, investigates experiences of the illness and healing process in different socio-cultural contexts [15]. After the focus group transcripts, interviews, and field notes were carried out by the main researcher, the transcribed information was read and reread by 2 researchers separately, thus increasing reliability. Content analysis techniques were performed manually to detect units of meaning and nexus categories. After identifying the codes, the authors met to discuss the findings of the themes related to the signs (category refers to symptoms that indicate the disease or suffering described in the patients' narratives), meanings (category refers to how the person perceives the problem and how s/he constructs, in their imagination, the received diagnosis), and practices (category refers to the creation of strategies to solve a specific problem of myelopathy). After the data was revised multiple times and a consensus was reached, the findings were compiled, and a matrix describing the most representative themes was created in the results section.

\section{Results}

The sample consisted of 38 people with HAM/TSP; the mean age was $54.2 \pm 10.28$ years. The majority of participants were women (57.89\%), of African descent (47.37\%), married (42.10\%), had completed primary schooling (36.84\%), and of the average socioeconomic class (55. 26\%). The mean disease duration was $11.45 \pm$ 8.31 years and mean body mass index (BMI) was $24.67 \pm$ $3.21 \mathrm{~kg} / \mathrm{m} 2$. Twenty (52.64\%) participants did not practice physiotherapy regularly and $23(60.53 \%)$ used a walking or gait devices (Table 1).

From the analyses of the information collected in the FGs and interviews, the following categories emerged: Signs-physical signs, symptoms, and discovery of the disease (Fig. 1); Meanings-reaction to the diagnosis, knowledge about the disease, fears and expectations (Fig. 2); Practices-activities of daily living, leisure activities, religious activities, and treatment (Fig. 3).

\section{Signs}

The Signs category refers to symptoms that indicate the disease or suffering described in the patients' narratives (Fig. 1).

Most participants shared the same symptoms of HAM/TSP, especially pain, pelvic floor dysfunction, weakness in the legs that led to loss of balance and falls. In the present study, dermatitis and uveitis were mentioned by only 1 participant each. Regarding discovery of the disease, most participants discovered the infection through blood donation, followed by prenatal examination and sexual partner examination. Loss of functionality also led patients to seek medical services.

\section{Meanings}

The category Meanings refers to how the person perceives the problem and how s/he constructs, in their imagination, the received diagnosis.

Fourteen respondents reported feelings of sadness and depression upon receiving the HAM/TSP diagnosis. Three patients felt the desire to die, feelings that demonstrate suffering and anguish permeate the imagination of these people. In contrast, 6 participants adopted a resilient 
Table 1 Sociodemographic and clinical characteristics of individuals with HAM/TSP of the CTHTLV of the Bahiana School of Medicine and Public Health, Salvador, Bahia, Brazil

\begin{tabular}{|c|c|c|}
\hline Variables & $N=38$ & N (\%) \\
\hline Age, years $(M \pm S D)$ & & $54.20 \pm 10.28$ \\
\hline \multirow[t]{2}{*}{ Sex } & Female & $22(57.89)$ \\
\hline & Male & $16(42.11)$ \\
\hline \multirow[t]{4}{*}{ Skin color } & Black & $18(47.37)$ \\
\hline & Mixed race & $17(44.73)$ \\
\hline & White & $3(7.9)$ \\
\hline & Yellow & $0(0)$ \\
\hline \multirow[t]{5}{*}{ Socioeconomic class } & A & $1(2.63)$ \\
\hline & B & $3(7.89)$ \\
\hline & $C$ & $21(55.26)$ \\
\hline & $\mathrm{D}$ & $12(31.59)$ \\
\hline & $E$ & $1(2.63)$ \\
\hline \multirow[t]{4}{*}{ Marital status } & Single & $10(26.32)$ \\
\hline & Married & $16(42.10)$ \\
\hline & Separated & $3(7.89)$ \\
\hline & Widowed & 9 (23.68) \\
\hline \multirow[t]{5}{*}{ Education Level } & Illiterate & $1(2.63)$ \\
\hline & Elementary School Incomplete & $10(26.32)$ \\
\hline & Elementary School complete & $14(36.84)$ \\
\hline & Secondary Education & $7(18.42)$ \\
\hline & Higher Education & $6(15.79)$ \\
\hline \multirow[t]{2}{*}{ Walking or gait devices } & Does not use & $15(39.47)$ \\
\hline & Uses & $23(60.53)$ \\
\hline \multirow[t]{2}{*}{ Physiotherapy } & Yes & $18(47.36)$ \\
\hline & No & $20(52.64)$ \\
\hline Disease duration, years $(\mathrm{M} \pm \mathrm{SD})$ & & $11.45 \pm 8.31$ \\
\hline $\mathrm{BMI}, \mathrm{kg} / \mathrm{m}^{2}(\mathrm{M} \pm \mathrm{SD})$ & & $24.67 \pm 3.21$ \\
\hline
\end{tabular}

$M$ Mean, $S D$ Standard deviation; Social Class $A$ and $B=$ high, $C=$ average; $D$ and $E=$ low (parameters IBGE, Brazil); BMI Body mass index

stance as a way to adapt to change and overcome adversity.

Among the fears and expectations, most respondents cited marital problems, financial loss, loss of productive capacity, need for family support, fear of people's reaction, and fear of falling. They also welcomed the potential benefits of health care and expressed hope about research and treatment. We observed the presence of family support, mainly from mothers and wives, in most of the narratives. However, in some cases the support came from strangers.

\section{Practices}

The Practices category refers to the creation of strategies to solve a specific problem of myelopathy.

Regarding the practices of the exercise programme, all respondents reported greater autonomy and balance. Obstacles such as lack of self-discipline, financial problems, low levels of education, walking difficulties, and cultural factors make it tough to adhere to exercise protocols. Ten participants indicated a preference for performing exercises in the clinic, even though they knew how to do the exercises alone. According to them, in addition to socialization, working in the clinic increases their confidence in safely, correctly executing the exercises. There is a need for multidisciplinary rehabilitation centers for outpatient treatment of individuals with HAM/TSP that are comprised of professionals prepared to promote care for this population.

Nine interviewees indicated that going to church, regardless of religion, is an act of exercise of faith and socialization. Preaching was also cited by 5 patients. Praying was another way of contacting the Divine. Only 1 interviewee, of the African religion Candonblé, reported talking to his orixa as a way of exercising faith and asking for problem-solving advice. 


\begin{tabular}{|c|c|}
\hline $\begin{array}{c}\text { SIGNS } \\
\begin{array}{c}\text { Categories and subcategories (number of } \\
\text { participants) }\end{array}\end{array}$ & Participant's voice \\
\hline \multicolumn{2}{|l|}{$\begin{array}{l}\text { Physical Signs and Symptoms } \\
\end{array}$} \\
\hline 1) Pain (26) & $\begin{array}{l}\text { "I discovered why I was full of pain" (G1P3); "I feel a } \\
\text { lot of pain, [...] the other day I was in so much pain, } \\
\text { but it was pain that I could not stand or walk in the } \\
\text { house." (G2P8) }\end{array}$ \\
\hline 2) Pelvic floor dysfunction (18) & $\begin{array}{l}\text { "I had a lot of urinary infections." (G1P2); "I have } \\
\text { urinary incontinence and a lot of pain." (G4P20) }\end{array}$ \\
\hline 3) Weakness in the legs (16) & $\begin{array}{l}\text { "I am feeling very weak, weak in my legs." (G1P5); } \\
\text { "I feel very tired, we feel a weakness." (G2P7) }\end{array}$ \\
\hline 4) Loss of balance and falls (12) & $\begin{array}{l}\text { "It kept dragging me, anything I fell, pain and } \\
\text { weight on my legs." (G4P14); "I started to fall, I fell } \\
\text { a lot, I fell over." (G1P2 and G3P13); "[...] had a } \\
\text { lack of balance in the legs." (G5P26) }\end{array}$ \\
\hline 5) Dermatitis and uveitis (2) & $\begin{array}{l}\text { "[...] is attacking my views, I worry a lot about losing } \\
\text { sight." (G2P6) "I had a dermatitis, I was sent here } \\
\text { and diagnosed." (G4P18) }\end{array}$ \\
\hline \multicolumn{2}{|l|}{ Discovery of Disease } \\
\hline 1) Blood donation (9) & $\begin{array}{l}\text { "I discovered through the Hemoba, by donating } \\
\text { blood." (G1P1); "The discovery was right here, I } \\
\text { went to donate blood and discovered that there." } \\
\text { (G4P15) }\end{array}$ \\
\hline 2) Pre-natal examinations (4) & $\begin{array}{l}\text { "I could not hold a pregnancy and when I was able } \\
\text { to hold it came along with the virus." (G6P29); "after } \\
\text { the second pregnancy I discovered it." (G4P20); "It } \\
\text { was at my wife's prenatal, when she did the blood } \\
\text { tests." (EP34) }\end{array}$ \\
\hline 3) Sex partner examination (2) & $\begin{array}{l}\text { "My husband was pulling his leg, after } 3 \text { years he } \\
\text { died, I started to fall, I took the exam and found out } \\
\text { about it." (G6P31) }\end{array}$ \\
\hline $\begin{array}{l}\text { 4) Findings in examinations carried out for other } \\
\text { reasons (5) }\end{array}$ & $\begin{array}{l}\text { "I discovered because I had a virus in sight, I did all } \\
\text { the exams and then the doctor identified." (EP36) }\end{array}$ \\
\hline 5) Loss of functionality (1) & $\begin{array}{l}\text { "I discovered in the dance, I realised that in some } \\
\text { steps I started to fail." (G7P33) }\end{array}$ \\
\hline
\end{tabular}

Fig. 1 Signs - Category and subcategories

\section{Discussion}

\section{General aspects of the sample}

The sociodemographic characteristics of the participants are similar to prior reports, in which most of the samples were composed of women [2, 3]. Our data further confirmed that the population most affected by HAM/ TSP has lower education and socioeconomic levels, is of African descent, and is married [4]. Most of the participants were middle-aged adults, which suggests a period of latency of the virus for several decades [6].

The median time of clinical manifestations varied from months to decades, which is a finding consistent with previous studies [4]. The use a walking or gait devices was present in more than half of the participants. This data highlights the pronounced functional disability, as reported in previous studies $[12,23]$. Despite this incapacity, the majority of the interviewees did not perform physiotherapy, a finding similar to a previous study [10]. The benefits of rehabilitation programs for this population are evident [9-11]. In the arsenal of techniques employed by physiotherapists, exercises are the main modality used to improve functional capacity and quality of life. The positive effects of home exercise programs underscore the prospect of assisting this population in today's contexts [24].

\section{Signs}

The highest reported symptom was daily pain, especially in the lower back and lower limbs [7, 8], which is data consistent with previous studies [24-26]. Pain is the principal complaint of those affected by the HAM/TSP and causes significant loss of quality of life [27]. Pelvic floor dysfunction was also reported by participants, especially women $[28,29]$. This situation interferes with social life because loss of urine, unpleasant odor, and need for absorbents indicates the fragility of these people. Additionally, the urgent need to urinate several times at night interferes with sleep quality and impairs sexual performance, self-care, and the willingness to perform various activities, all of which reduce self-esteem and self-confidence [30]. 


\begin{tabular}{|c|c|}
\hline $\begin{array}{l}\text { Meanings } \\
\begin{array}{c}\text { Categories and subcategories (number } \\
\text { of participants) }\end{array}\end{array}$ & Participant's voice \\
\hline \multicolumn{2}{|l|}{ Reaction to Diagnosis } \\
\hline 1) Indifference (2) & $\begin{array}{l}\text { "Knowing I was calm, because I did not know what it } \\
\text { was, there they explained [to] me and I was nervous." } \\
\text { (G6P31); "It did not shake me." (G6P32) }\end{array}$ \\
\hline 2) Sadness (14) & $\begin{array}{l}\text { "I was very sad [...] I was really sad, (pause), horrible." } \\
\text { (G2P6); "At first it was very difficult, I went into } \\
\text { depression, I did not want to see anyone, I did not go } \\
\text { anywhere." (G1P3) }\end{array}$ \\
\hline 3) Desire for death (3) & $\begin{array}{l}\text { "[... I came to SARAH one day, I do not even like to } \\
\text { remember, (choking voice) I was looking like I was } \\
\text { throwing myself under a car." (G2P6) }\end{array}$ \\
\hline 4) Resilience (6) & $\begin{array}{l}\text { "[... My illness I have already accepted, the good thing } \\
\text { for us is to accept because otherwise it is worse, if we } \\
\text { do not accept it is not helpful." (G8P13) }\end{array}$ \\
\hline \multicolumn{2}{|l|}{ Knowledge about Disease } \\
\hline 1) Unawareness of HTLV (8) & $\begin{array}{l}\text { "[... I did not even know what that was, I had never } \\
\text { even heard of it, when I heard about HTLV, I thought I } \\
\text { had AIDS, it's confusing, they're related." (G1P2) }\end{array}$ \\
\hline 2) Searching information on the Internet(4) & $\begin{array}{l}\text { "[...] curious as I am, I searched the Internet to really } \\
\text { know what this was." (G10P35) }\end{array}$ \\
\hline 3) Information in reference Centres (12) & $\begin{array}{l}\text { "When I was in SARAH I learned to extract urine every } \\
6 \text { hours (catheterisation)." (G1P3) }\end{array}$ \\
\hline \multicolumn{2}{|l|}{ Fears and Expectations } \\
\hline 1) Conjugal problems (7) & $\begin{array}{l}\text { "I discovered in 2001, it was precisely at that time that I } \\
\text { got divorced [...] but the greatest impact was not to } \\
\text { know about the disease, because from that point on } \\
\text { came the separation [pause, cry and silence]." (G2P7) }\end{array}$ \\
\hline 2) Financial losses (1) & $\begin{array}{l}\text { "I think work was the joy I had, without work I was } \\
\text { swept off the floor, retirement is little in comparison to } \\
\text { what I earned, I earned a lot more." (G7P33) }\end{array}$ \\
\hline 3) Loss of productive capacity (1) & $\begin{array}{l}\text { "[...] it was a thump when the INSS expert said that he } \\
\text { was going to send me to a reorganisation in the } \\
\text { administrative sector, which I would no longer teach." } \\
\text { (G8P14) }\end{array}$ \\
\hline 4) Need for family support (8) & $\begin{array}{l}\text { "[...] today my quality of life has improved a lot and } \\
\text { since I have a family that gives me support, I have } \\
\text { daughters, which helps a lot." (G2P2); "[...] my wife is } \\
\text { wonderful, takes good care of me, I have nothing to } \\
\text { complain about." (G3P1) }\end{array}$ \\
\hline 5) Fear of people's reaction (10) & $\begin{array}{l}\text { "People in general have a prejudice of everything: } \\
\text { social, racial, cultural and because of this, I do not } \\
\text { want to go through this, because I know that if people } \\
\text { are prejudiced with me I will suffer, and that is where } \\
\text { my immunity will go." (G10P29) }\end{array}$ \\
\hline 6) Fear of falls (5) & $\begin{array}{l}\text { "Because the pavements all are broken, we can slip." } \\
\text { (G1P5); "I had to leave work because I was not taking } \\
\text { any more because of the falls, I took a lot of falls." } \\
\text { (G1P3) }\end{array}$ \\
\hline 7) Reception of the health team (20) & $\begin{array}{l}\text { "The distance does not matter; the important thing is } \\
\text { the affection that you give to us." (G9P34) "I cannot } \\
\text { speak all the good that the staff did for me, so that was } \\
\text { helping me [...]." (G10P29) }\end{array}$ \\
\hline 8) Hope with research and treatment (10) & $\begin{array}{l}\text { "To maintain balance, [...] I am sure that according to } \\
\text { the teachings and guidelines the tendency is to even } \\
\text { improve." (G1P2); "Improve in pain, in weakness." } \\
\text { (G2P3) }\end{array}$ \\
\hline
\end{tabular}

Fig. 2 Meaning-Category and subcategories

Weakness in the legs, loss of balance, and falls were also cited as frequent symptoms according to related literature [7]. The risk of falling is a public health problem because the consequences bring great suffering and increased expenses resulting from surgeries and hospitalization [31, 32]. These issues cause more withdrawal social behavior 


\begin{tabular}{|c|c|}
\hline $\begin{array}{c}\text { Practices } \\
\text { Categories and subcategories (number of } \\
\text { participants) }\end{array}$ & Participant's voice \\
\hline \multicolumn{2}{|l|}{$\begin{array}{l}\text { Daily Life Activities } \\
\end{array}$} \\
\hline 1) Domestic practices (15) & $\begin{array}{l}\text { "I clean the yard, I make food, I do everything, I } \\
\text { have a 4-year-old son, I play basketball, I ride a } \\
\text { bicycle, I have a dog, I have a large acerola foot. I } \\
\text { go to the market, I shop, I do everything." (EP34) }\end{array}$ \\
\hline 2) Going to the street (2) & $\begin{array}{l}\text { "[... I I eat lunch on the street, I watch television, I } \\
\text { stay on the computer, I live alone, I do not do any } \\
\text { of this. I do not like it very much and because I am } \\
\text { not able anymore (domestic activities)." (EP35); "I } \\
\text { am retired. I do not do anything. I live alone. I } \\
\text { have a person who makes food, cleans the house } \\
\text { and everything else." (EP36) }\end{array}$ \\
\hline 3) Hiring employees (2) & $\begin{array}{l}\text { "Sometimes I go out, I do something to } \\
\text { complement my salary, I like to stay in the street, I } \\
\text { do not like to stay in the house anymore, if I stay } \\
\text { at home, I just think of foolish things, in this } \\
\text { agony. I never got married." (EP35); "The thing I } \\
\text { most do is go to the market. Every time I stretch I } \\
\text { go to the market, because it's physiotherapy for } \\
\text { me." (EP36) }\end{array}$ \\
\hline 4) Difficulties with collective transportation (6) & $\begin{array}{l}\text { "For me it will be transportation, because } \\
\text { transportation is difficult." (G1P10); "I myself when } \\
\text { it's raining can't imagine coming here, because it's } \\
\text { a difficult time for us to come." (G1P5) }\end{array}$ \\
\hline \multicolumn{2}{|l|}{ Leisure Activities } \\
\hline 1) Sports (2) & $\begin{array}{l}\text { "I go out with my children, ride a bicycle and take } \\
\text { my son and everything by bicycle." (EP17); "My } \\
\text { fun is more the beach, I swim, I take my son to } \\
\text { swim, sometimes surfing." (E4T) }\end{array}$ \\
\hline 2) Culture (6) & $\begin{array}{l}\text { "I go to the beach, I go to carnival, I go out to } \\
\text { dance, I try to have fun, I travel during Saint John } \\
\text { festivities, I dance forró and samba." (EP28); "Ah, } \\
\text { I like to cross-stitch." (EP6); "Sometimes I go in } \\
\text { the machine, sometimes I go to the sewing } \\
\text { machine, I make crafts with scraps of cloth." } \\
\text { (EP37); "I travel inland." (EP12) }\end{array}$ \\
\hline 3) Entertainment (11) & $\begin{array}{l}\text { "One time or another there is something to read, I } \\
\text { can have a movie to watch, who has a phone and } \\
\text { a computer does not have solitude." (EP7) }\end{array}$ \\
\hline \multicolumn{2}{|l|}{ Religious Activities } \\
\hline 1) Go to church (9) & $\begin{array}{l}\text { "I am evangelical, I go to church, I am part of the } \\
\text { CWA, which is Christian Women in Action, every } \\
\text { Sunday morning, I go to church." (EP2); "I really } \\
\text { like going to church." (EP6) }\end{array}$ \\
\hline 2) Prayers (2) & $\begin{array}{l}\text { "Agreed, I make my prayers." (EP37); "Read the } \\
\text { word of God." (EP5) }\end{array}$ \\
\hline 3) Preaching (5) & $\begin{array}{l}\text { "[...] as I am a witness of Jehovah, I go forth, I } \\
\text { preach." (G9P1); "I am evangelical, I even preach } \\
\text { the gospel." (G3P11) }\end{array}$ \\
\hline 4) Consultation with spiritual guide: orixá (1) & $\begin{array}{l}\text { "I have a candomblé yard [...] My Orixá sent me to } \\
\text { see a doctor with his head, he cannot speak. For } \\
8 \text { years he's been trying to tell me about it, put it in } \\
\text { my head." (G6P2) }\end{array}$ \\
\hline \multicolumn{2}{|r|}{ 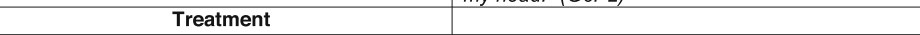 } \\
\hline 1) Improvement in autonomy (6) & $\begin{array}{l}\text { "[...] I feel more willing, I go out myself, I have } \\
\text { been to Feira de Santana alone, I thank God." } \\
\text { (G9P12); "[...] when I do physiotherapy I feel } \\
\text { stronger, more excited, right, because, it is a hope } \\
\text { even though physiotherapy will not cure the } \\
\text { disease, it will make me much better." (G1P2) }\end{array}$ \\
\hline 2) Improved functionality (6) & $\begin{array}{l}\text { "You do not need anyone, I do it myself." } \\
\text { (G10P34); "You do not need a physiotherapist [...] } \\
\text { I do every other day." (G10P17); "To me it does } \\
\text { not matter." (G10P1) }\end{array}$ \\
\hline 3) Improving self-esteem (14) & $\begin{array}{l}\text { "When I do, I feel like there's an improvement, it's } \\
\text { important to me, it's everything, that's all. My } \\
\text { greatest improvement is due to exercise." } \\
\text { (G4P19) }\end{array}$ \\
\hline 4) Lack of discipline(4) & $\begin{array}{l}\text { "It is laziness, it is embarrassment, it is emotional } \\
\text { problems, it is family problems, it is religious } \\
\text { problems, it is economic problems, in fact, } \\
\text { everything influences." (EP7); There is a little bit } \\
\text { of laziness." (G11P9) }\end{array}$ \\
\hline 5) Preference for outpatient treatment (10) & $\begin{array}{l}\text { "[...] I do but I think that in the presence of the } \\
\text { physiotherapist is much better." (G7P5); "[...] } \\
\text { physical therapy I think is good, but really doing } \\
\text { [it] here we feel better, because it has people to } \\
\text { correct, encourage us [...] would do it alone, but I } \\
\text { want to come here too, because it encourages } \\
\text { more." (G9P12) }\end{array}$ \\
\hline
\end{tabular}

Fig. 3 Practices_Category and subcategories 
and decrease the ability to perform day-to-day work and activities that were previously executed. Furthermore, dermatosis has been documented with a high frequency in symptomatic [33] and asymptomatic individuals [8, 34]. Genital candidiasis, associated in most cases with urinary incontinence [35], was also reported. The association between ocular manifestations and people infected with HTLV-1 has also been reported [36]. Although the literature evidences the presence of dermatosis and eye problems in patients with HAM/TSP, these symptoms were rarely reported in the present study.

The discovery of the disease was casual in general. These findings indicate the need to include ELISAs in routine basic care for the early detection of HTLV-1 in endemic areas, such as Salvador [5]. Blood banks have been the main detection site, thanks to Ordinance No. 1376 of the Ministry of Health [37]. The prohibitive cost of testing is a limiting factor for screening in economically disadvantaged countries [38]. A study conducted in Japan showed that through public policy actions, with the insertion of serological testing in pregnant women and interruption of breastfeeding of seropositive women, vertical transmission was reduced from 20 to 3\% [39].

\section{Meaning}

Most respondents shared the presence of mental disorders, in the face of disease progression, as well as loss of the ability to work and enjoy leisure time. The reaction to the diagnosis corresponds to the stages of mourning described by Elizabeth Kubler Ross [40]. Acceptance of the disease does not occur immediately after diagnosis. Untroubled acceptance will usually only occur after decades, when the patients become more adherent to the therapeutic programs [41].

Health professionals and society in general have a profound lack of knowledge about HTLV infection, and this knowledge gap has implications for both diagnosis and care practice. The fact that only $1-5 \%$ of the infected develop symptoms makes it difficult to implement public policies aimed at this population and perpetuates the spread of the virus [8]. Indeed, HTLV is an "invisible" virus; its spread generally occurs silently in the population [41]. Coping with the disease should be approached in the biopsychospiritual model recommended by the WHO [42], namely by a team aware of the psychological stages expected after the diagnosis and who can guide the minimization of adverse reactions. The rise of the Internet has favored health literacy [43]. However, the number of websites that do not guarantee quality information is still significant. Only limited content is available on the HTLV-1.

Health centers are sought in the hope of finding other more effective treatments with the hope that one day a cure will be discovered [44]. HTLV-1 is a sexually transmitted disease, thus often affecting marital relationships.
Suffering often stems from a sense of betrayal due to a partner's extramarital affairs and/or a lack of encouragement in seeking new partners due to fears of infecting others. Issues include loss of libido, perineal hypersensitivity, vaginismus, pelvic floor hypertonia caused by neuromotor changes, and impaired sexual activities and pleasure [30]. In addition, premature menopause is common in infected women [28]. This complex scenario reduces the quality of life. Socio-educational actions are fundamental for the practice of protected sex and reduction of the number of sexual partners that increase the risks of contamination.

Another factor involved in chronic diseases is the commitment of financial resources of patients and their families. The transition from productive worker to retired due to disability markedly reduces wages and consequently lowers the socioeconomic status [45]. The most affected individuals are frequently the family providers; changes in social roles become necessary. In addition to a reduction in the ability to provide for her/ his family, symptomatic people often become dependent and vulnerable [12]. Spending on diapers, transportation, and exams increases. These purchases, coupled with reduced income, require substantial family rearrangements and decrease the purchasing power of all involved.

Loss of days at work, medical leave, and early retirement generate high costs for the entire society [45]. The subjects often feel unable to contribute socially and feel shame and fear of bothering others, which generates great suffering and social exclusion. The families undergo major changes in their composition [46]. They are the primary source of support for HTLV-1seropositive people. The family should seek support, security, affection, and respect, all of which are fundamental elements for better coping.

\section{Practices}

Individual or group exercise programs, at the clinic or at home, are recognized as useful for improving function in this population [9-11]. However, difficulties with selfdiscipline limit the implementation of home programs in Brazil [10].

The chronic degenerative evolution of HAM/TSP leads to the need for the use of walking aids, such as canes, walkers, and wheelchairs and total dependence on care from others in the final phase of the disease [23, 27]. This condition reduces recreational and sports activities, which lead to physical inactivity and increase the risk of comorbidities [31]. Cell phones and computers were reported as important forms of leisure.

It is also clear that spiritual practice affects the health of people with HTLV. Although religious diversity in Brazil demonstrates that the country has become secular, the search for a religious meaning for practical 
experience is fundamental to addressing health problems. In the present study, most women sought to exercise their faith in various ways while men were in the minority. Instead, they chose to preach. Spirituality is part of the constitution of all men, regardless of any spiritual experience [47].

\section{Implications for clinical practice and future research}

This study is the first qualitative research that involves people with HAM/TSP, assisted at CTHTLV. The knowledge gained from this study by authorities and health professionals may promote greater understanding of the needs that permeate this population. This awareness can contribute to the implementation of public policies, focused on the real perspective of these patients, through more targeted care that is empathic and harmonious for these individuals.

Future research should aim to solve the problems presented in the current study, including accessibility, public policies, knowledge about the virus, physiotherapy, and leisure, among others.

\section{Conclusions}

It can be concluded that people with HAM/TSP suffer from symptoms that are limiting their social participation. They are affected by complex and multidimensional feelings. Activities of daily living, including leisure, spiritual, and therapeutic assistance, help in coping with this neglected health condition. Public policies should be implemented to allow an integrated multidisciplinary team to minimize the effects of this infection on the quality of life of these people.

\begin{abstract}
Abbreviations
ADAB: Assisting teaching ambulatory; CTHTLV: Integrative and Multidisciplinary Center for Assistance and Research to Family and HTLV Carriers of the Bahiana School, Salvador; CAFIS: Advanced physiotherapy clinic; EBMSP: Bahia School of Medicine and Public Health; ELISA: Enzymelinked immunosorbent assay; HAM/TSP: Human T-cell lymphotropic virus type 1 associated myelopathy/tropical spastic paraparesis; HEMOBA: Bahia State Hematology and Hemotherapy Foundation; HTLV-1: Human T-cell lymphotropic virus type 1; RCT: Randomized clinical trial; SARAH: Network of rehabilitation hospitals; WHO: World Health Organization
\end{abstract}

\section{Acknowledgements}

The authors would like to gratefully acknowledge the patients who generously shared their experiences as part this research effort. We also acknowledge the Integrative and Multidisciplinary Center for Assistance and Research to Family and HTLV Carriers of the Bahiana School, Salvador, Bahia, Brazil.

\section{Authors' contributions}

Study concept and design contributors were GOS, MP and KNS. Data analyses and interpretation were performed by GOS, AML and AVG. The manuscript was written by GOS and KNS and revised by all authors. The authors read and approved the final manuscript.

\section{Funding}

Not applicable. This research did not have any funding sources.
Availability of data and materials

http://www7.bahiana.edu.br//jspui/handle/bahiana/2919

\section{Competing interests}

The authors declare that they have no competing interests.

\section{Ethics approval and consent to participate}

The project was approved by the Research Ethics Committee of the Bahiana School of Medicine and Public Health, under the CAAE

13568213.8.0000.5544, and obeyed the Helsinki Declaration of 1964 and subsequent amendments. All participants who agreed to participate in the study signed the informed consent form.

\section{Consent for publication}

All individual participants provided consent for the publication of this study's results as a part of the informed consent process.

\section{Author details}

${ }^{1}$ Department of Post Graduate, Bahiana School of Medicine and Public Health, Salvador, Bahia, Brazil. 'Multidisciplinary Reference Center for Assistance and Research for Family and Patients with HTLV the Assisting Teaching the Bahia School of Medicine and Public Health, Salvador, Bahia, Brazil.

Received: 5 June 2019 Accepted: 16 April 2020

Published online: 04 May 2020

References

1. Poiesz, B. J., Ruscetti, F. W., Gazdar, A. F., Bunn, P. A., Minna, J. D., \& Gallo, R. C. (1980). Detection and isolation of type $C$ retrovirus particles from fresh and cultured lymphocytes of a patient with cutaneous T-cell lymphoma. Proceedings of the National Academy of Sciences of the United States of America, 77, 7415-7419. https://doi.org/10.1073/pnas.

2. Romanelli, L. C. F., Caramelli, P., \& Proietti, A. B. F. C. (2010). Human T-cell lymphotropic virus type 1 (HTLV-1): When you suspect the infection? Revista da Associação Médica Brasileira, 56(3), 340-347. https://doi.org/10.1590/ S0104-42302010000300021.

3. Gessain, A., \& Cassar, O. (2012). Epidemiological aspects and word distribution of HTLV-1 infection. Frontiers in Microbiology, 3(388), 1-23. https://doi.org/10.3389/fmicb.2012.00388.

4. Catalan-Soares, B., Carneiro-Proietti, A. B. F., \& Proietti, F. A. (2005). Heterogeneous geographic distribution of human T-cell lymphotropic viruses I and II (HTLV-I/II): Serological screening prevalence rates in blood donors from large urban areas in Brazil. Cadernos Public Health, 21, 926-993. https://doi.org/10.1590/S0102-311X2005000300027.

5. Dourado, I., Alcantara, L. C., Barreto, M. L., Da Gloria, T. M., \& Galvao-Castro, B. (2003). HTLV-I in the general population of Salvador, Brazil: A city with African ethnic and sociodemographic characteristics. Journal of Acquired Immune Deficiency Syndromes, 34(5), 527-531.

6. Osame, M., Usuku, K., Izumo, S., ljichi, N., Amitani, H., Igata, A., et al. (1986). HTLV-I associated myelopathy, a new clinical entity. Lancet, 1, 1031-1032. https://doi.org/10.1016/S0140-6736(86)91298-5.

7. Ribas, J. G. R., \& Melo, G. C. N. (2002). Myelopathy associated with human Tcell lymphotropic virus type 1 (HTLV1). Brazillian Journal of Tropical Medicine, 35, 377-384. https://doi.org/10.1590/S0037-86822010000600013.

8. Einsiedel, L., Spelman, T., Goeman, E., Cassar, O., Arudell, M., \& Gessain, A. (2014). Clinical associations of human t-lymphotropic virus type 1 infection in an indigenous Australian population. PLoS Neglected Tropical Diseases, 8 , e2643. https://doi.org/10.1371/journal.pntd.0002643.

9. Borges, J., Baptista, A. F., Santana, N., Souza, I., Kruschewsky, R. A., GalvãoCastro, B., et al. (2014). Pilates exercises improve low back pain and quality of life in patients with HTLV-1 virus: A randomized crossover clinical trial. Journal of Bodywork and Movement Therapies, 18, 68-74. https://doi.org/10. 1016/j.jbmt.2013.05.010.

10. Facchinetti, L. D. (2013). The effects of a home exercise program in patients with tropical spastic paraparesis/myelopathy associated with HTLV-1 (PET) MAH) [internet]. Rio de Janeiro: National Institute of Infectology Evandro Chagas. https://doi.org/10.1038/sc.2012.134.

11. Neto, I. F., Mendonça, R. P., Nascimento, C. A., Mendes, S. M. D., \& Sá, K. N. (2010). Muscular strengthening in patients with HTLV-1 and its influence on functional performance. Research Journal of Physiotheraphy, 2(2), 143-155. 
12. Coutinho, I. J., Galvão-Castro, B., Lima, J., Castello, C., Eiter, D., \& Grassi, M. F. R. (2011). Impact of myelopathy associated with HTLV/tropical spastic paraparesis (TSP/HAM) on daily living activities (ADL) in patients infected with HTLV-1. Acta Fisiatr, 18(1), 6-10. https://doi.org/10.5935/0104-7795. 20110001.

13. Gascón, M. R. P., Santos, R. F., Captain, C. G., Fantine, N. M. C., \& Oliveira, A. C. P. (2013). A body that loses its meaning: A psychoanalytic reading of patients with tropical spastic paraparesis. Rev SBPH, 16(1), 33-48.

14. WHO. Letter from Ottawa. Ministry of Health/FIOCRUZ. (1986). Health promotion: Letters from Ottawa, Adelaide, Sundsvall and Santa Fé de Bogotá. Brasilia: Ministre of Health/IEC.

15. Uchôa, E., Firmo, J. O. A., Dias, E. C., Pereira, M. S. N., \& Gontijo, E. D. (2002). Signs, meanings and actions associated with Chagas disease. Cadernos Public Health, 18(1), 71-79. https://doi.org/10.1590/S0102311X2002000100008

16. Macêdo, M. C., Mota, R. M., Patrício, N. A., Baptista, A. F., Andrade-Filho, A. S., \& Sá, K. N. (2019). Pain and quality of life in human T-cell lymphotropic virus type 1-associated myelopathy or tropical spastic paraparesis after homebased exercise protocol: A randomized clinical trial. Journal of Brazillian Society Tropical Medicine, 52, e20180270. https://doi.org/10.1590/0037-86820270-2018.

17. Castro-Costa, C. M., AQC, A., Barreto, M. M., et al. (2006). Proposal for diagnostic criteria for tropical spastic paraparesis/HTLV-I-associated myelopathy (TSP/HAM). AIDS Research and Human Retroviruses, 22, 931-935. https://doi.org/10.1089/aid.2006.22.931.

18. Kitzinger, J., \& Barbour, R. S. (1999). Introduction: The challenge and promise of focus groups. In J. Kitzinger \& R. S. Barbour (Eds.), organizers Developing focus group research: Politics, theory and practice (pp. 1-20). London: Sage.

19. Ressel, L. B. (2003). Vivenciando a sexualidade na assistência de enfermagem: Um estudo na perspectiva cultural [tese]. São Paulo: Universidade de São Paulo. Programa Interunidades de Doutoramento em Enfermagem.

20. Dall'Agnol, C. M., \& Trench, M. H. (1999). Grupos focais Como estratégia metodológica em pesquisas na Enfermagem. Rev Gaúcha Enferm, 20(1), 525 .

21. Debus, M. (1997). Manual Para excelencia en la investigación mediante grupos focales. Washington, DC: Academy for Educational Development.

22. lervolino, S. A., \& Pelicioni, M. C. F. (2001). The use of the focal group as a qualitative methodology in health promotion. Rev ESC Enf USP, 35(2), 115121.

23. Franzoi, A. C., \& Araujo, A. Q. (2007). Disability and determinants of gait performance in tropical spastic paraparesis/HTLV-I associated myelopathy (TSP/HAM). The Journal of Spinal Cord, 45(1), 64-68. https://doi.org/10.1038/ s..sc.3101919.

24. Sá, K. N., Macêdo, M. C., Andrade, R. P., Mendes, S. D., Martins, J. V., \& Baptista, A. F. (2015). Physiotherapy for human T-lymphotropic virus Iassociated myelopathy: Review of the literature and future perspectives. Journal of Multidisciplinary Healthcare, 8, 1-9. https://doi.org/10.2147/JMDH. S71978.

25. Tavares, I. R., Franzoi, A. C., \& Araujo, A. Q. C. (2008). Low back pain following HTLV-1 associated myelopathy/tropical spastic paraparesis (TSP/HAM). The Brazilian Journal of Infectious Diseases, 12(Suppl 1), S5.

26. Mendes, S. M. D., Baptista, A., Sá, K. N., Andrade, D. C. A., Otero, G. G., Cavalcanti, J. Z., et al. (2013). Pain is highly prevalent in individuals with tropical spastic paraparesis. Health Care, 1(3), 47-53. https://doi.org/10. 12966/hc.11.01.2013.

27. Martins, J. V. P., Baptista, A. F., \& Araújo, A. Q. C. (2012). Quality of life in patients with HTLV-I associated myelopathy/tropical spastic paraparesis. Arquivos de Neuro-Psiquiatria, 70(4), 257-261. https://doi.org/10.1590/S0004282X2012005000006.

28. Andrade, R., Tanajura, D., Santan, D., \& Carvalho, E. M. (2013). Association between urinary symptoms and quality of life in HTLV-1 infected subjects without myelopathy. International Brazilian Journal of Urology, 39, 861-866. https://doi.org/10.1590/S1677-5538.IBJU.2013.06.13.

29. Rocha, P. N., Rehem, A. P., Santana, J. F., Castro, N., Muniz, A. L., Salgado, K., et al. (2007). The cause of urinary symptoms among human T lymphotropic virus type I (HLTV-I) infected patients: Across sectional study. BMC Infectious Diseases, 7(15), 1-7. https://doi.org/10.1186/1471-2334-7-15.

30. Diniz, M. S. C., Feldner, P. C., Castro, R. A. C., Sartori, M. G. F., \& Girão, M. J. B. C. (2009). Impact of HTLV-I in quality of life and urogynecologic parameters of women with urinary incontinence. European Journal of Obstetrics, Gynecology, and Reproductive Biology, 147, 230-233.
31. Shublaq, M., Orsini, M., \& Puccioni-Sohler, M. (2011). Implications of HAM/ TSP functional incapacity in the quality of life. Arquivos de Neuro-Psiquiatria, 69(2A), 208-211. https://doi.org/10.1590/S0004-282X2011000200013.

32. Facchinette, L. D., Araújo, A. Q., Chequer, G. L., De Azevedo, M. F., De Oliveira, R. V. C., \& Lima, M. A. (2013). Falls in patients with HTLV-I-associated myelopathy/tropical spastic paraparesis (TSP/HAM). Spinal Cord, 51, 222-225.

33. Lenzi, M. E. R., Cuzzi-Maya, T., Oliveira, A. L. A., Andrade-Serpa, M. J., \& Araujo, A. Q. C. (2003). Dermatology findings of human T Iymphotropic virus type I (HTLVI) - associated myelopathy/tropical spastic paraparesis. Clinical Infectious Diseases, 36, 507-513. https://doi.org/10.1111/ijd.12170.

34. Gonçalves, D. U., Guedes, A. C., Proeitti, A. B., Martins, M. L., Proietti, F. A., \& Lambertucci, J. R. (2003). Dermatology lesions in asymptomatic blood donors seropositive for human T cell lymphotropic virus type-l. The American Journal of Tropical Medicine and Hygiene, 68, 562-565.

35. Guedes, A. M. C., \& Araujo, M. G. (2006). Dermatological manifestations associated with HTLV-1 (pp. 165-173). Belo Horizonte: Caderno de Hemominas.

36. Soares, R. M. G., \& Moraes Jr., H. V. (2000). Ocular manifestations observed in HTLV-I seropositive patients in Rio de Janeiro. Arquivos Brasileiros de Oftalmologia, 63, 317-322. https://doi.org/10.1590/S000427492000000400010.

37. Public Health Department (Brazil) (1993). Ordinance no. 1376 of November 19, 1993. Approves changes to Administrative Rule no. 721 / GM, of 09.08. 89, which approves Technical Norms for the collection, processing and transfusion of blood, components and derivatives, and other measures. Federal Official Gazette; section 1.

38. Carneiro-Proietti, A. B., Catalan-Soares, B. C., Castro-Costa, C. M., Murphy, E. L., Sabino, E. C., Hisada, M., Galvão-Castro, B., Alcantara, L. C., Remondegui, C., Verdonck, K., \& Proietti, F. A. (2006). HTLV in the Americas: Challenges and perspectives. Panamericana Salud Publica, 19, 44-53. https://doi.org/10.1590/ S1020-49892006000100007.

39. Kashiwagi, K., Furusyo, N., Nakashima, H., Kubo, N., Kinukawa, N., Kashiwagi, S., et al. (2004). A decrease in mother-to-child transmission of human $T$ lymphotropic virus type I (HTLV-I) in Okinawa. Japan-American Journal of Tropical Medicine and Hygiene, 70(2), 158-163.

40. Kubler-Ross, E. (1992). On death and dying (pp. 51-150). São Paulo: Martins Fontes.

41. Zihlmann, K. F. (2009). From the invisibility to the visibility of the subject living with the infection/disease of the human T-cell lymphotropic virus type 1 (HTLV1) and the place of reproductive decisions in the frames of knowledge and careThesis. São Paulo: University of São Paulo.

42. Fleck, M. P. A., Borges, Z. N., Bolognesi, G., \& Rocha, N. S. (2003). WHOQOL development, spirituality module, religiosity and personal beliefs. Rev Saúde Pública, 37(4), 446-455. https://doi.org/10.1590/\$0034-89102003000400009.

43. Santos, M., Paixão, R., \& Osorio-de-Catro, C. G. (2013). Health literacy evaluation of human research subjects. Rev Redbioética/UNESCO Year 4, 1(7), 84-95. ISSN 2077-9445.

44. Orge, G., Travassos, M. J., \& Bonfim, T. (2009). Living with HTLV-I. Gaz Méd Bahia, 79(1), 68-72.

45. Cassaes, N. R. R. (2007). Social support and stigma: A study among people with HIV/AIDSMaster's thesis. Salvador: UFBA.

46. Petrini, J. C., \& Dias, M. (2016). Marital and family relations in contemporary society. In L. Moreira (Ed.), Family relationships (Vol. 2). Curitiba: CRV Publishing House.

47. Tyler, J. V., Tracy, A. B., \& Howard, K. (2017). Health and spirituality. JAMA, 318(6), 519-520. https://doi.org/10.1001/jama.2017.8136.

\section{Publisher's Note}

Springer Nature remains neutral with regard to jurisdictional claims in published maps and institutional affiliations. 